\title{
The Role of Time Perspective and Peer Rejection in Predicting High-Risk Behaviors of Adolescents of Yazd City
}

\section{Zohre Tajabadi}

MA in General Psychology, Department of Psychology, Faculty of Psychology and Educational Sciences, Yazd University, Yazd, Iran

\section{Fahimeh Dehghani}

* Assistant Professor, Department of Psychology, Faculty of Psychology and Educational Sciences, Yazd University, Yazd, Iran. (Corresponding Author): Email: f.dehghani@yazd.ac.ir

\section{Maryam Salehzadeh}

Assistant Professor, Department of Psychology, Faculty of Psychology and Educational Sciences, Yazd University, Yazd, Iran

Received: 25 June 2019

Accepted: 25 November 2019

Doi: 10.29252/ijhehp.8.2.129

\section{ABSTRACT}

Background and Objective: Today, high risk behaviors in adolescents have become one of the most important concerns of society which are influenced by various factors. Time perspective is how one perceives or evaluates past, present, and future that greatly influences on its decisions. Peer rejection is also one of the variables that has received special attention in the area of adolescent behaviors. Therefore, the present study was conducted with the aim of investigating the role of time perspective and peer rejection in predicting high-risk behaviors of adolescents of Yazd city.

Materials and Methods: This study was descriptive cross-sectional. Statistical population consisted of adolescents aged 15-17 that from them 378 persons were selected using quota sampling method. The tool used in this study was Time Perspective Questionnaire, Iranian Adolescents Risk-Taking Scale, and Peer Rejection Questionnaire. Descriptive and inferential statistics including Pearson correlation test and multiple regression analysis were used for data analysis. Results: The results of regression analysis showed that in girls, among the dimensions of the time perspective, only the past negative dimension $(p=0.03)$ could predict high-risk behaviors and in boys the past negative $(p=0.001)$, past positive $(p=0.04)$ and present fatalistic $(p=0.006)$ are predictors of high-risk behaviors. Peer rejection was not able to predict high-risk behaviors in any of the groups ( $p>0.05)$.

Conclusion: According to the findings, time perspective is one of the factors affecting the high-risk behaviors of adolescents. Therefore, psychological education based on time perspective can be effective on high-risk behaviors.

Keywords: Time Perspective, Peer Rejection, High Risk Behaviors, Adolescents Paper Type: Research Article.

Citation (Vancouver): Tajabadi Z, Dehghani F, Salehzadeh M. The Role of Time Perspective and Peer Rejection in Predicting High-Risk Behaviors of Adolescents of Yazd City. Iran J Health Educ Health Promot. Spring 2020;8(2): 129-141. [Persian]x

- Citation (APA): Tajabadi Z., Dehghani F., Salehzadeh M. The Role of Time Perspective and Peer Rejection in Predicting High-Risk Behaviors of Adolescents of Yazd City. (Summer 2020). Conc... . Iranian Journal of Health Education \& Health Promotion., 8(2), 129-141. [Persian] 


\section{نقش :ششمانداز زمانى و طرد همسالان در بِيشبينى رفتار هاى برخطر نوجوانان شهر يزد}

\section{جكيده بونان}

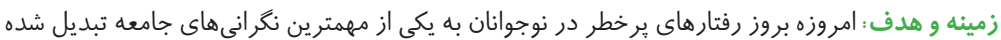

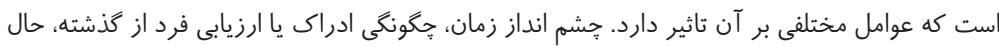

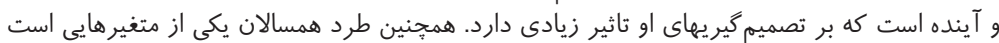

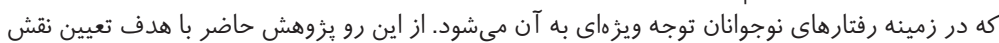

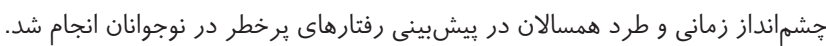

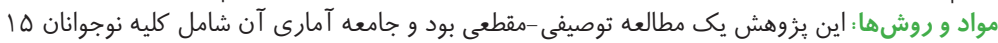

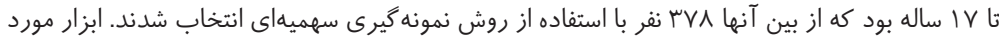

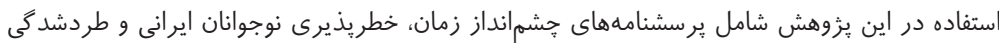

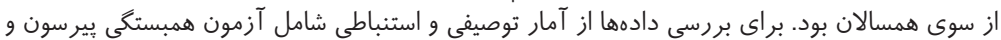

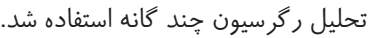

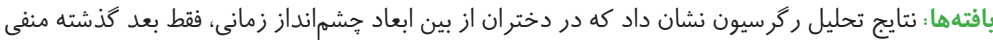

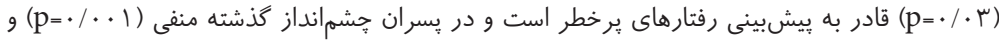

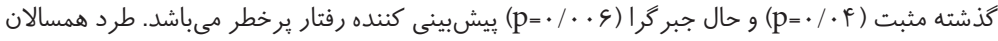

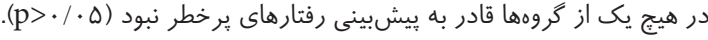

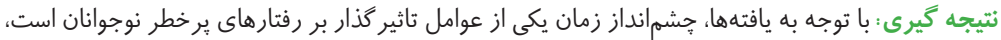

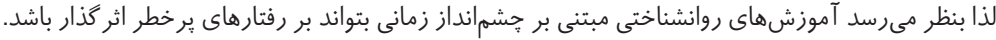

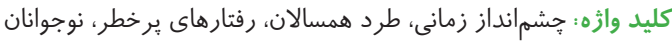

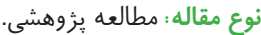

4 استناد (ونكوور): تاج آبادى ز،دهقانى ف، صالحزاده م. نقش جشمانداز زمانى و طرد همسالان در يِيشبينى

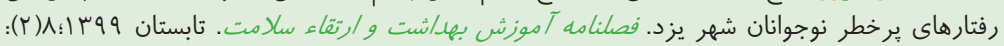

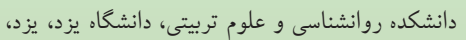


نوجوانى دوره اى است كه با تغييرات سريع جسمانى، شناختى و اجتماعى مشخص ميشود. اين تحولات معمولا در جهار حوزه رشد مطابق تحقيقات انجام شده عوامل متعددى در بروز رفتارهاى

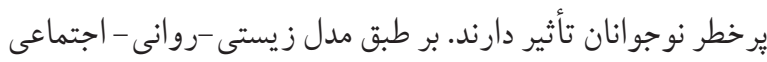

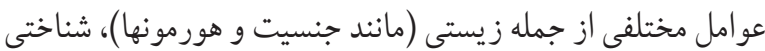
(ادراى از خطر و عزت نفس) و اجتماعى (شيوهاى فرزنديرورى

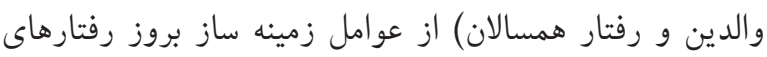

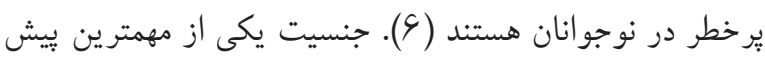

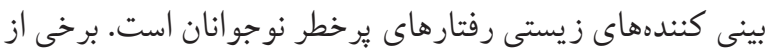

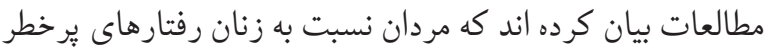

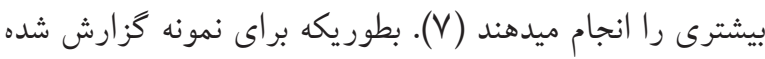

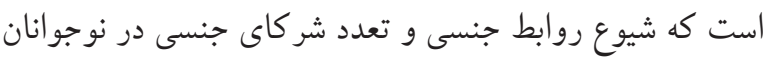

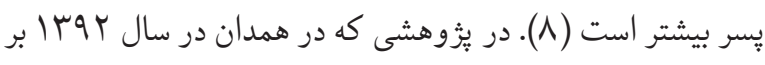

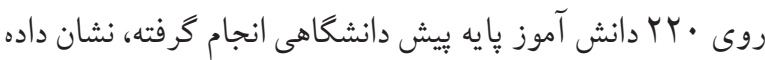

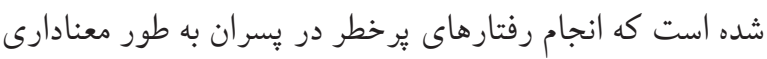

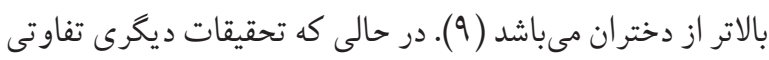

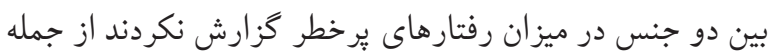

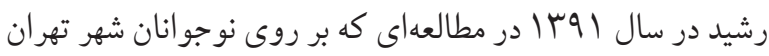

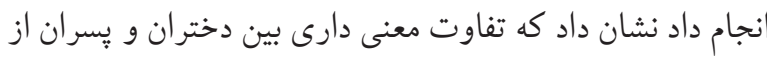
نظر تجربه كشيدن قليان، كشيدن سيخار، رابطه جنسى، كتك كارى

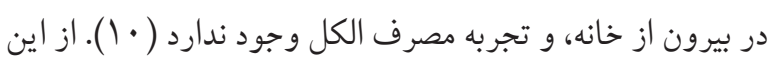
رو به نظر مىرسد بيشبينى كنندههاى رفتارهاى برخطر در دختران

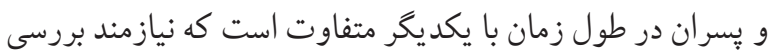

$$
\text { بيشتر مىباشد. }
$$

از سوى ديكر همانكونه كه ذكر شد عوامل شناختى از جمله متغيرهاى بيش بينى كننده رفتارهاى بر خطر هستند. يكى از عوامل

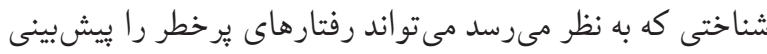

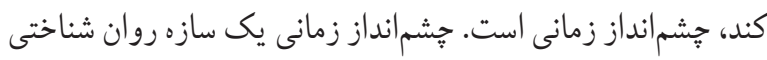

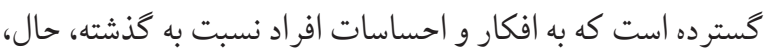
و آينده اشاره دارد (11) و شيوهاى است كه افراد و فرهنخها،

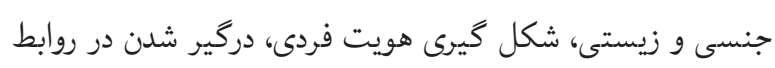

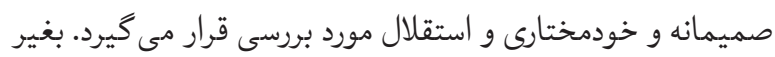

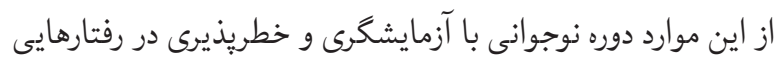
كه ممكن است سلامتى و رفاه حال و زندگى آينده فرد را مختل كند،

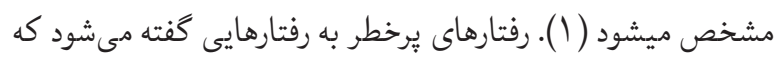

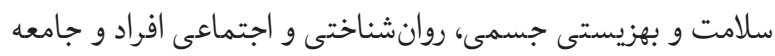
را به خطر مى اندازد. رفتارهاى برخطر را مى توان به دو گروه تقسيم

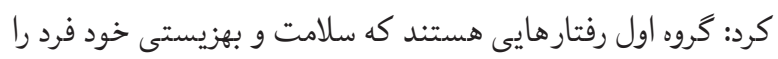
به خطر مياندازد مثل مصرف مواد مخدر، الكل، سيگار و رفتارهاى ردهاى

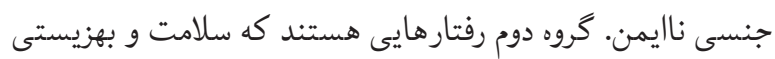

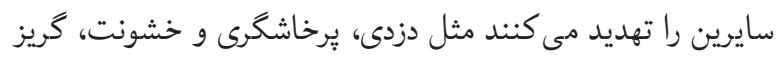

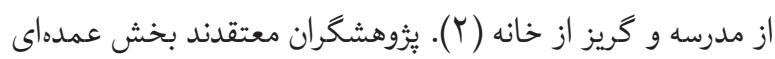

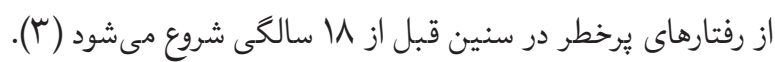
در زمينه ميزان شيوع رفتارهاى يرخطر مطالعه اى كه در كشور

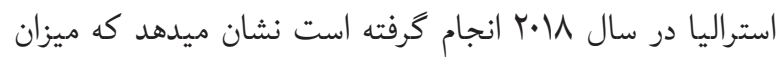

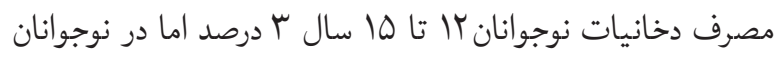

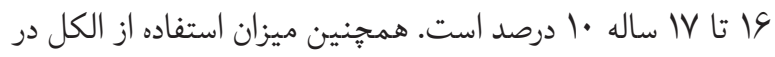

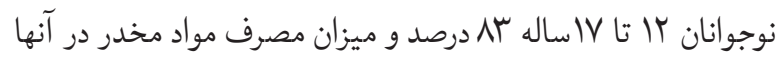

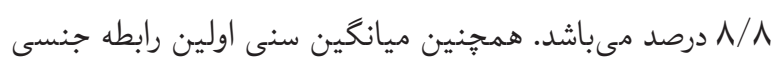
IV •اله نوجوانان دختر و پِسر مقطع متوس_طه ش-هر قـزوين نشان.

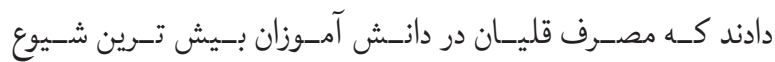

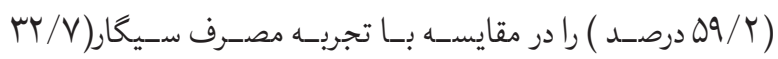
درصد)، تجربه مصرف مواد مخدر (V/T درصد) و مصرف الكل

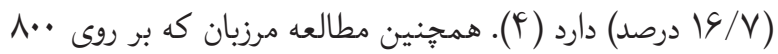

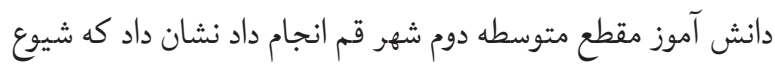

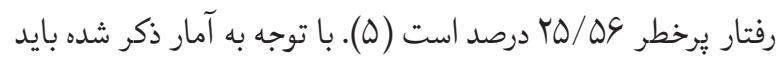
توجه داشت كه شيوع رفتارهاى يرخطر در بين نوجوانان و جوانان 
همسالان در زندگى وى افزايش مى يابد(9 (1). بنابراين توجه وى به يذ يرش و طرد همسالان نيز بيشتر مى گردد. علت اصلى و عمدهاى

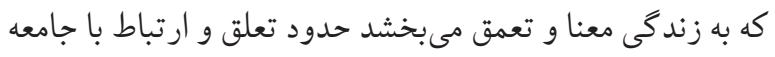
است، بر اين اساس براى نوجوانانى كه احساس كمبود يا فقدان

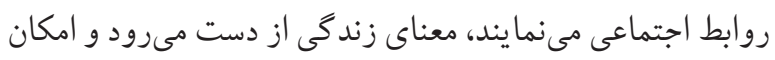

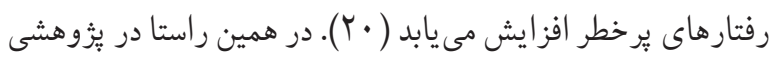

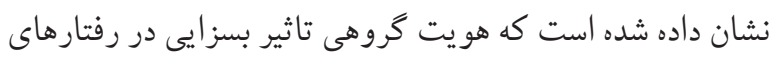

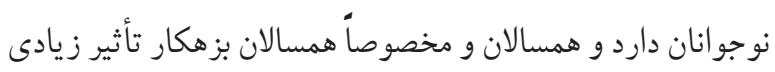

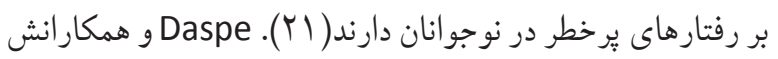

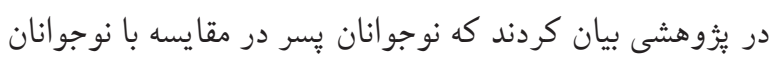

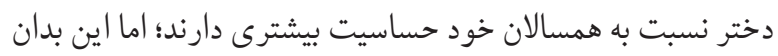

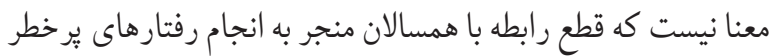
از سوى نوجوانان مىشود: بلكه آنان تلاش مى كنند تا با همسالان

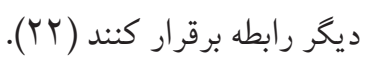

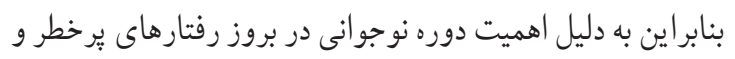

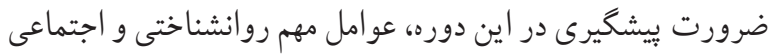

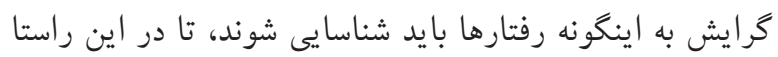

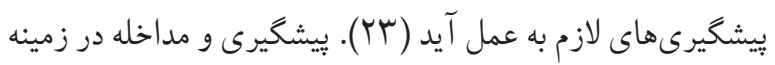

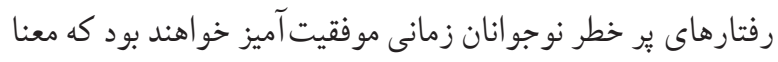

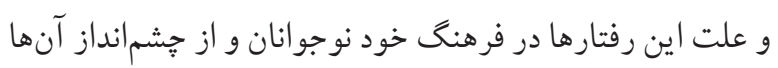

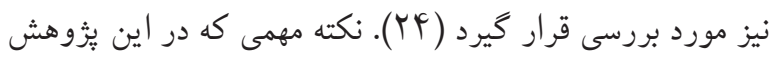

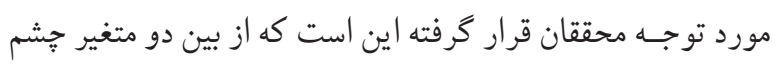

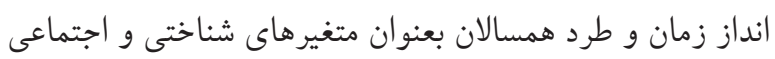
كداميك اهميت بيشترى در بيش بينى رفتارهاى برخطر دارند.

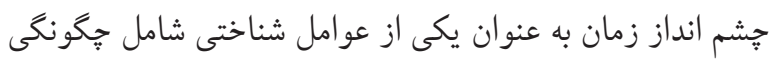

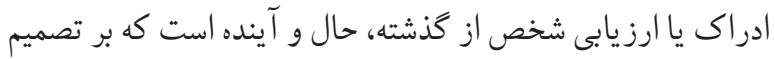

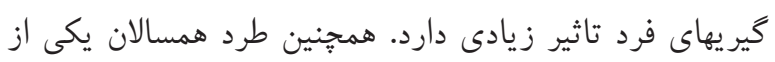
مولفههاى اجتماعى است كه در زمينه رفتارهاى نوجوانان توجه

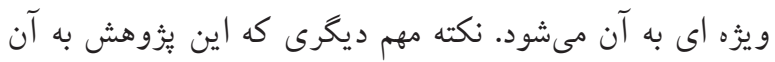

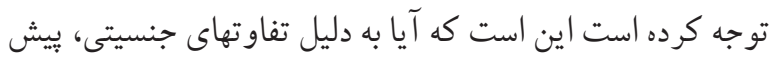

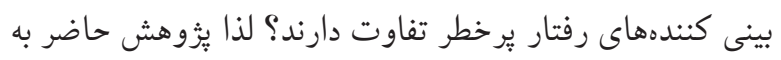

تجارب انسانى را درون جارجوب هاى زمانى معنا مى كنند( I I).

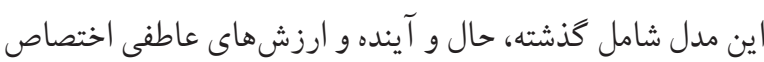

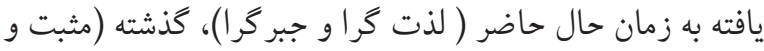

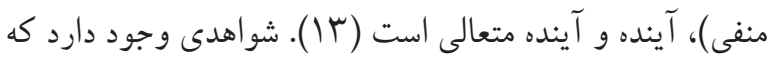

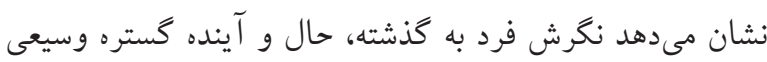
از تصميمات و اعمال او را تحت تأثير قرار مىدهد. به طور مثال

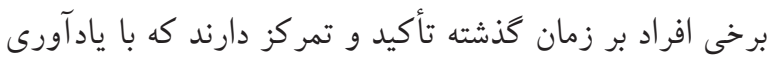

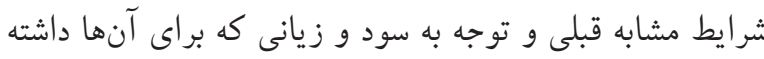

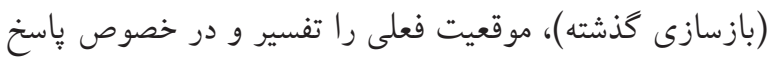

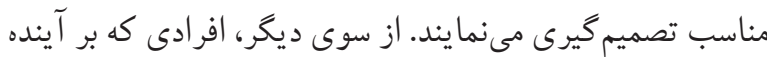

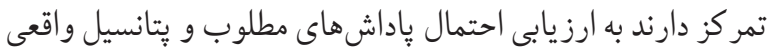
موانع و حالشها يرداخته و سيس به تصميم گيرى اقدام مى كنند و

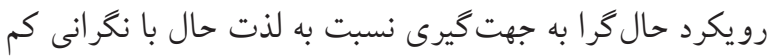

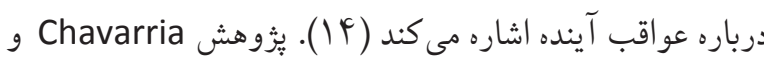

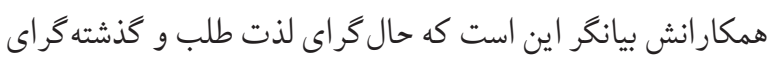
منفى به طور معنادارى مصرف الكل و عواقب مصرف مواد را

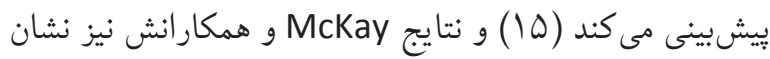

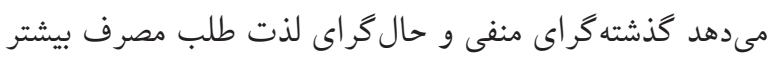

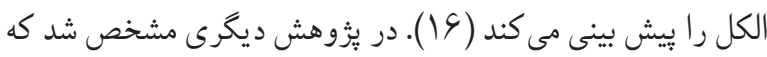

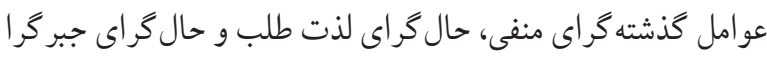
ييشبينى كننده معنادار رفتار يرخطر در افر اد معتاد است (IV)

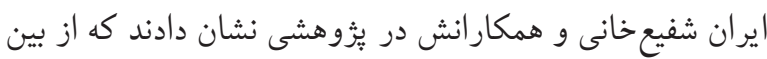

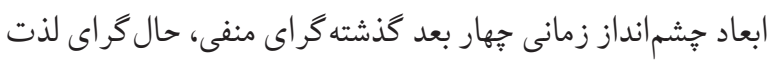

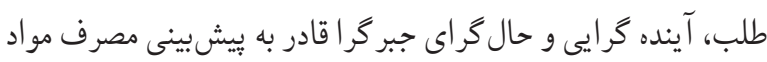

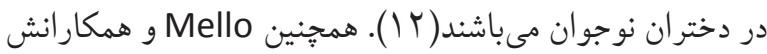

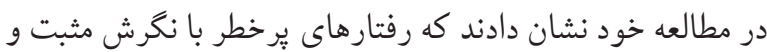
منفى نسبت به زمان حال ارتباط دارد (1) (1). همانكونه كه نتايج

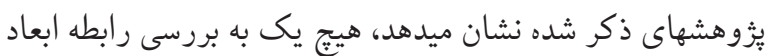
جشم انداز زمان با رفتارهاى يرخطر به تفكيك جنسيت نيرداخته اند.

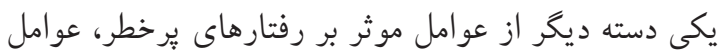

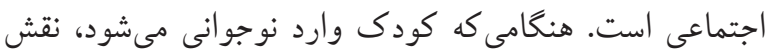




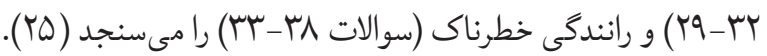
بايد توجه داشت كه خرده مقياس رانندگى خطرناك به دليل عدم

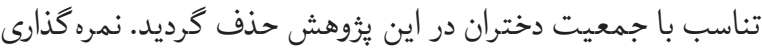
اين يرسشنامه بر اساس طيف ليكرت ه درجهاى (كاملا مخالفم

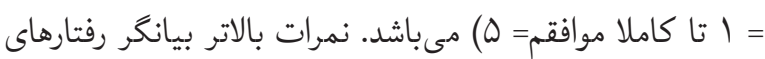

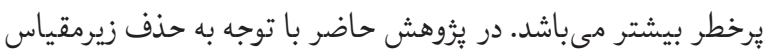

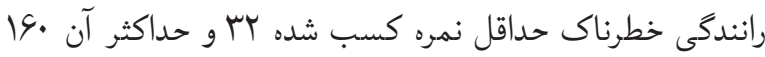

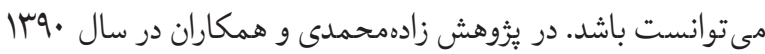
روايى اين مقياس توسط و روانشناس و متخصص مسائل جوانان مورد بررسى و تاييد قرار گرفت، همجنين پِيايايى ابزار نيز با استفاده

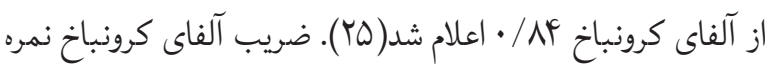
كل مقياس در يُوهش حاضر اA / • به دست آمد.

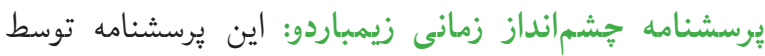
Boyd و Zimbardo

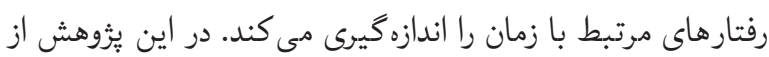

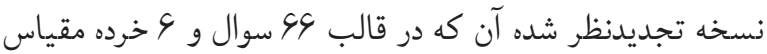

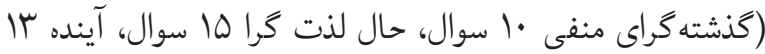

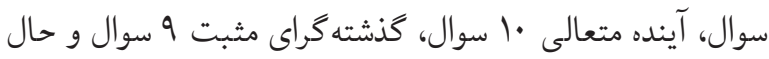

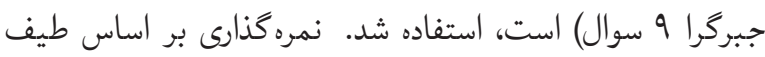

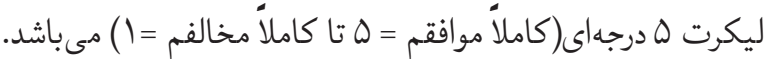
در نتيجه حداكثر و حداقل نمرات زيرمقياسها مى تواند گذشته كراى

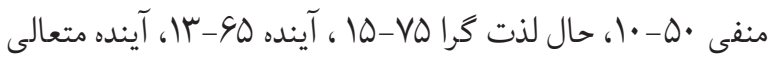

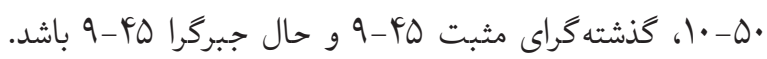

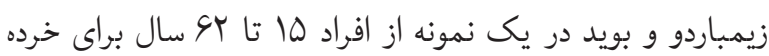

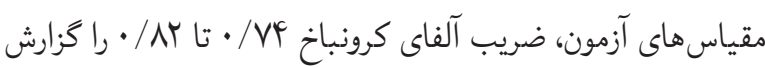

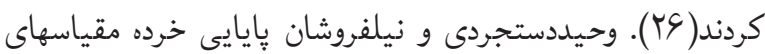

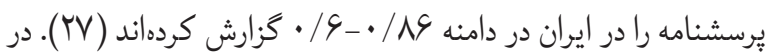

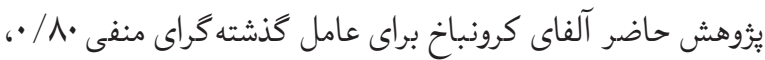

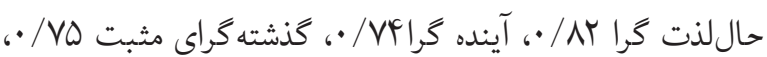

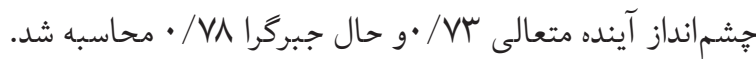
آزمون طرد هـمسالان: اين آزمون توسط طهماسيان و در قالب 10
تعيين نقش جشم انداز زمانى و طرد همسالان در يِشبينى رفتارهاى يرخطر نوجوانان يُرداخته است.

مواردو ورشها يُؤهش حاضر مطالعه اي توصيفى-مقطعى بود كه جامعه آمارى

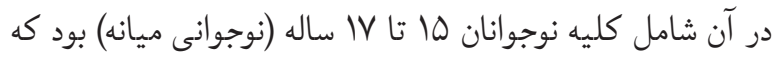
در سال تحصيلى 91-9V و در پايههاى تحصيلى دهم و يازدهم

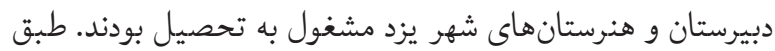

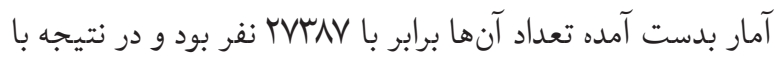

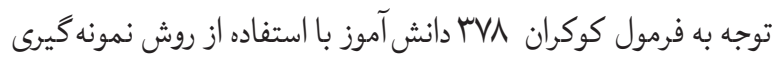

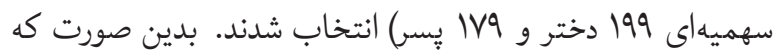
جهار دبيرستان و دو هنرستان دخترانه و پِرانه كه تمايل به همكارى

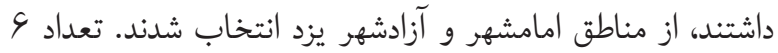
كلاس از پايههاى دهم و يازدهم (هر پايه ץ كلاس) دبيرستانهاى

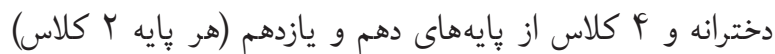

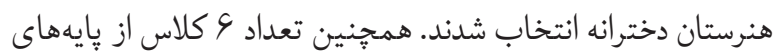

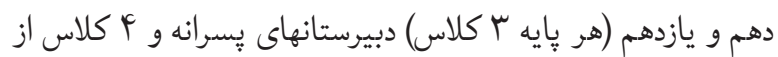

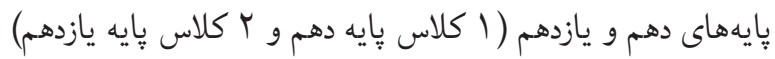
هنرستان يسرانه انتخاب شدند. پِ از تصويب يرو يوزال و اخذ مجوز كتبى از دانشـعاهو و

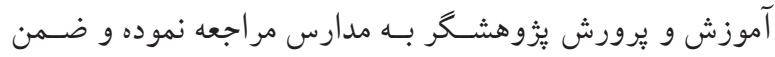

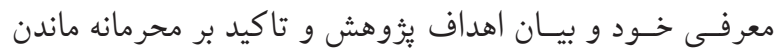
اطلاعـات و كسب رضايت كتبى اقــدام به توزيع برسشنامه وها كرد. در اين يُزوهش سه يُسشنامه خطر پِذيرى نوجوانان، جشمانداز

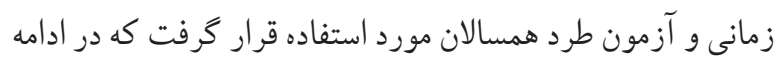
به تفصيل توضيح داده شده است. مقياس خطر پذيرى نوجوانان ايرانى: نسخه اصلى اين مقياس

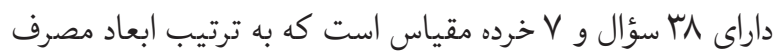

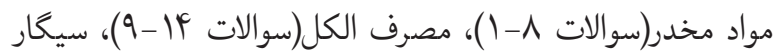

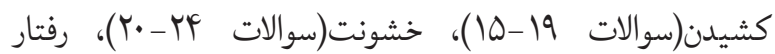

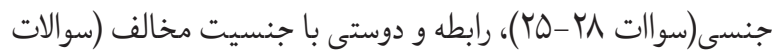


دو بخش آمار توصيفى (ميانگين و انحراف معيار) و آمار استنباطى

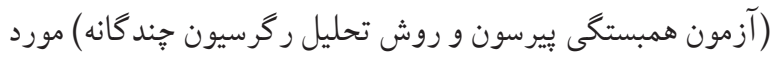

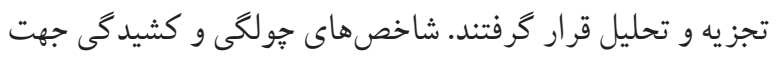
تعيين نرمال بودن دادهها مورد بررسى قرار كرفت كه در نهايت

يافتها نشان داد تمام متغيرها داراى توزيع نرمال مى باشند.

\section{يافتهاه ها}

با بررسى مشخصات دموكرافيك مى توان بيان كرد، 119 نفر از

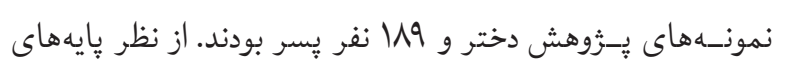

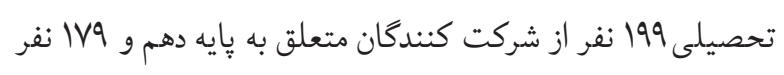

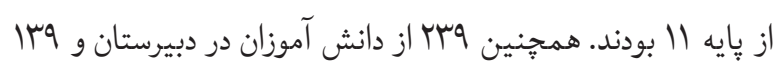

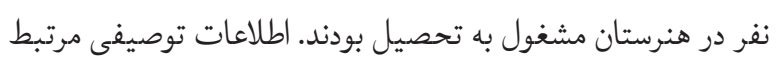
با متغيرهاى يُزوهش از جمله ميانكين، انحراف معيار، كمترين و

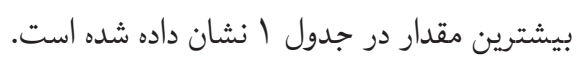

سوال طراحى شده است كه احساس نوجوان از مطرود يا محبوب بودن را در كروه همسالان مى سنجد. اين يرسشنامه داراى دو خرده مقياس

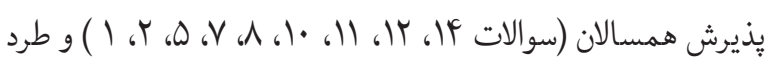

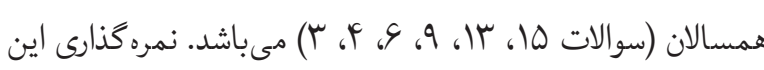
يرسشنامه بر اساس طيف ليكرت له درجهاى بوده و از (قويا در مورد

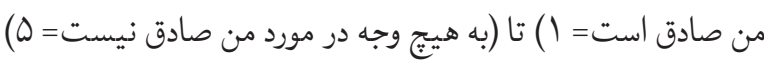

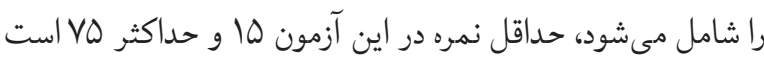
اعتبار آزمون طرد همسالان از طريق بازآزمايى به فاصله دو هفته آنه

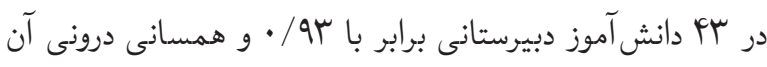

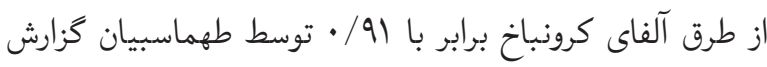

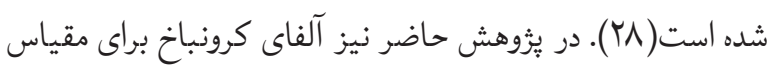

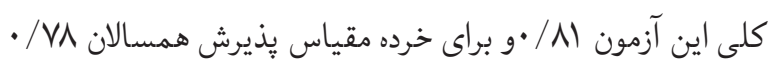

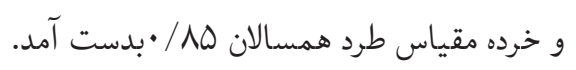

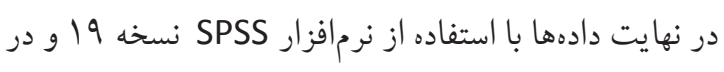
جدول ا : اطلاعات توصيفى مر تبط با رفتارهاى يرخطر و زيرمقياسهاى آن، جشم انداز زمانى و طرد همسالان

\begin{tabular}{|c|c|c|c|c|c|}
\hline & بيشترين مقدار & كمترين & انحراف معيار & 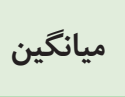 & متغير هاى بزوهش \\
\hline- & $11 \pi$ & er & $11 / \cdot 1$ & $\vee 9 / 11$ & ر فتارهاى يرخطر \\
\hline$r / F F$ & re & $\wedge$ & r/A & $19 / 0 r$ & 1-گرايش به مواد مخدر \\
\hline$r / \mu q$ & $r \mu$ & $\checkmark$ & $r / 99$ & $\mid r / \mu q$ & r-كرايش به الكل \\
\hline$r / \Delta \mu$ & rF & $\checkmark$ & $r / \Lambda$. & $1 F / 1 r$ & س-كرايش به سيخار \\
\hline$r /$ ro & rl & $\Delta$ & $r / V \mu$ & $11 / V F$ & 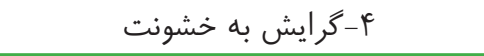 \\
\hline r/r人 & r & $\Delta$ & $r / \Delta \mu$ & $9 / 94$ & ه- گرايش به رابطه و رفتار جنسى \\
\hline \multirow[t]{2}{*}{$r / \mu \Delta$} & 19 & r & $r / \Lambda \Lambda$ & $q / \mu q$ & ه- گرايش به رابطه با جنسيت مخالف \\
\hline & & & & & جشم انداز زمانى \\
\hline$r / \varsigma q$ & $\Delta$ & re & $r / \Delta 0$ & Hs/As & |-ديد كاه زمانى گذشته-منفى \\
\hline$r / F r$ & $9 V$ & 19 & $s / V$ & $\mu s / \mu l$ & r-ديدگاه زمانى حال-لذت گرا \\
\hline$r / 91$ & $s t$ & rt & $4 / .9$ & $\varphi \& / 94$ & سـ-ديدكاه زمانى آينده \\
\hline$r / \varsigma$. & $\Delta$. & 10 & $\Delta / r$. & $\mu \mathrm{G} / \cdot \mu$ & Fأ-ديدكاه زمانى آينده متعالى \\
\hline$r / \Delta r$ & is & 9 & $4 / 10$ & 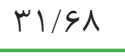 & ه-ديد كاه زمانى كذشته-مثبت \\
\hline$r / \mu r$ & ro & 9 & c/mo & $r \cdot / \Lambda \Lambda$ & 9-ديد گاه زمانى حال معتقد به سرنوشت \\
\hline- & sr & rl & V/VQ & $r q / \Delta q$ & طرد همسالان \\
\hline
\end{tabular}


با توجه به اينكه تعداد سو الات در هر زيرمقياس متفاوت بود به كرايش به خشونت و كرايش به رابطه با جنسيت مخالف بود.

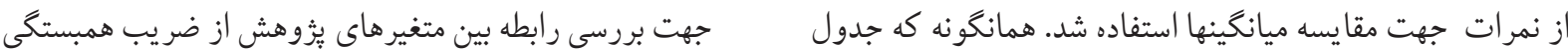

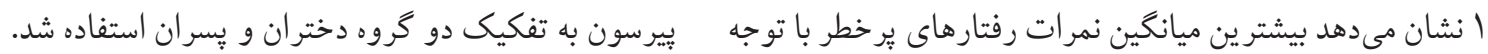
به تعداد سو الات متعلق به كرايش به سيخار و كمتر ين نمره مربوط جدول ץ: ماتريس همبستگى متغير هاى يُوهش در گروه دختران

\begin{tabular}{|c|c|c|c|c|c|c|c|c|}
\hline$\wedge$ & $\checkmark$ & 9 & $\Delta$ & f & $r$ & $r$ & 1 & متغير \\
\hline & & & & & & & 1 & 1 - كذشته منفى \\
\hline & & & & & & 1 & $-\cdot / 99^{* * * *}$ & r- حال لذت گرا \\
\hline & & & & & 1 & $-\cdot / \mathcal{F} \gamma^{* * * * a *}$ & $\cdot|9|^{* * * *}$ & r- آ آينده \\
\hline & & & & 1 & $\cdot / \Delta r^{* * * *}$ & $-\cdot / \mathscr{F} \Delta^{* * * *}$ & $\cdot / \mathcal{F} V^{* * * *}$ & F- آينده متعالى \\
\hline & & & 1 & 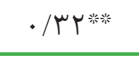 & $\cdot / \mathscr{A} r^{* * * * *}$ & $-\cdot / \Gamma \Lambda^{* * * * *}$ & 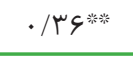 & ه- كذشته مثبت \\
\hline & & 1 & $-\cdot /$ 个粎 & $-\cdot / \Delta \Delta^{* * * *}$ & $-\cdot 109^{* * * *}$ & 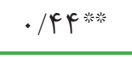 & $-\cdot \mid \Delta F^{* * *}$ & 4- حال جبركرا \\
\hline & 1 & .1 .4 &.$/ . \mu$ &.$- / .4$ & $-\cdot / 11$ & $-\cdot / \cdot 1$ & $.114^{*}$ & V- طرد همسالان \\
\hline 1 &.$/ .9$ & $\cdot /\left.\right|^{* * * * * *}$ & 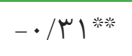 & $-\cdot / \Gamma \bigvee^{* * * *}$ & $-\cdot / q^{\text {䊉 }}$ & $\cdot / \mathcal{F}^{\mu * w *}$ & 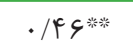 & 1- رفتارهاى برخطر \\
\hline
\end{tabular}

يافتهاى جدول Y نشان مى دهد در گروه دختران ضر يب همبستگى اما طرد همسالان با رفتارهاى برخطر رابطه معنادار نداشت.

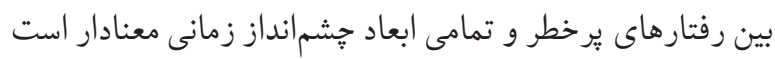

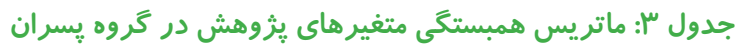

\begin{tabular}{|c|c|c|c|c|c|c|c|c|}
\hline$\Lambda$ & V & $\varepsilon$ & $\Delta$ & f & $r$ & $r$ & 1 & متغير \\
\hline & & & & & & & 1 & 1 - كذشته منفى \\
\hline & & & & & & 1 & $-\cdot / 9\}^{\text {米粰 }}$ & r- حال لذت گرا \\
\hline & & & & & 1 & 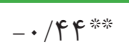 & $\cdot / 09^{* * * * *}$ & " ا- آينده \\
\hline & & & & 1 & $\cdot / 9 V^{\text {莎彞 }}$ & $-\cdot|\Delta|^{\text {粆深 }}$ & $\cdot 109^{\text {米搅 }}$ & F - آينده متعالى \\
\hline & & & 1 & 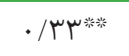 & · & $-\cdot / 1$ & $\cdot /\left.r\right|^{\text {米米 }}$ & ه- كذشته مثبت \\
\hline & & 1 & $-\cdot / 19^{\text {米粠 }}$ & 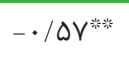 & $-\cdot / \Delta V^{\text {米粰 }}$ & $\cdot / \Delta \Delta^{\text {拳䄅 }}$ & $-\cdot|4|^{\text {粪莎 }}$ & צ- حال جبر گرا \\
\hline & 1 & $\cdot /\left.\Upsilon\right|^{\text {米粰 }}$ & $-\cdot / \cdot 9$ & 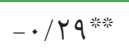 & $-\cdot / \Gamma \Delta^{\text {䅴 }}$ & $\cdot / r \Lambda^{\text {粰 }}$ & $-\cdot / 19^{*}$ & - طرد همسالان - V \\
\hline 1 & $\cdot / 19^{*}$ & 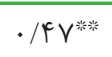 & $-\cdot / r r^{\text {米粰 }}$ & 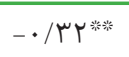 & $-\cdot / \Gamma \Delta^{\text {类粠 }}$ & 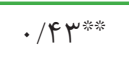 & 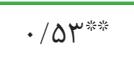 & 1- رفتارهاى پرخطر \\
\hline
\end{tabular}

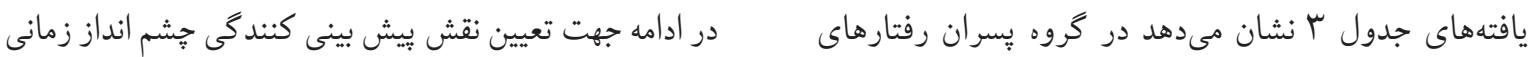

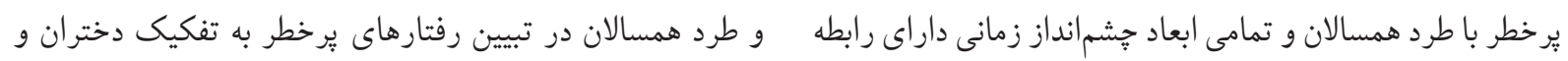

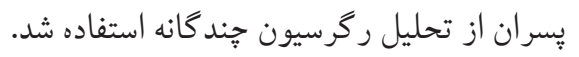


جدول ⿷匚: ضرايب مدل رگرسيون جهت ييشبينى رفتارهاى پرخطر

\begin{tabular}{|c|c|c|c|c|c|c|c|c|}
\hline معنى دارى سطح & F & مجذور ضريب & ضمبستغى & معنى دارى سطح & $\mathbf{t}$ & ضريب بتاى استاندارد & مدل & جنسيت \\
\hline \multirow{8}{*}{$\cdot / \cdot \cdot 1$} & \multirow{8}{*}{$1 \cdot / 1 \lambda F$} & \multirow{8}{*}{.$/ Y 9 \Delta$} & \multirow{8}{*}{$\cdot / \Delta F F$} & $\cdot / \cdots 1$ & s/AV^ & - & ضريب ثابت & \multirow{8}{*}{ دختر } \\
\hline & & & & سץ./. & $r / l \Delta r$ & . & كذشته-منفى & \\
\hline & & & & $\cdot / \cdot \Delta \Lambda$ & $1 / 9 \cdot 0$ &.$/ 19 V$ & حال-لذت گرا & \\
\hline & & & &.$/ r q r$ & $-1 / \cdot \Delta r$ & -.1 .90 & آينده & \\
\hline & & & & .1 .91 & $-1 / V \cdots$ & -||$f \mid$ & آ ينده متعالى & \\
\hline & & & & $\cdot / \cdot 19$ & $-1 / V I r$ &.$- / 1 \mathrm{rF}$ & كذشته-مثبت & \\
\hline & & & &.$/ 4 q 4$ & $\cdot / 9 \wedge \Lambda$ &.$/ .4$. & حال جبر گرا & \\
\hline & & & & .1 .09 &.$/ 1 \mu$. &.$/ 1 \mu$. & طرد همسالان & \\
\hline \multirow{8}{*}{.$/ \cdots 1$} & \multirow{8}{*}{ IT/FrG } & \multirow{8}{*}{ 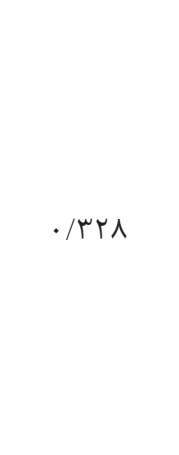 } & \multirow{8}{*}{$\cdot / \Delta V \mu$} & $\cdot / \cdot \cdot 1$ & سM & - & ضريب ثابت & \multirow{8}{*}{ يֶس } \\
\hline & & & & $.1 \cdot \cdot 1$ & r/Arv & . & كذشته-منفى & \\
\hline & & & & $\cdot / r \cdot V$ & $1 / r \& V$ & $\cdot / 1 \cdot 1$ & حال-لذت گرا & \\
\hline & & & & ./SH人 & $-\cdot / F V r$ &.$/ \cdot \mu \mu$ & آينده & \\
\hline & & & &.$/ 191$ & $-1 / 4 \cdot \Lambda$ &.$- / 1 r \Delta$ & آ ينده متعالى & \\
\hline & & & & $.|\cdot|+1$ & $-r / \cdot G \mu$ & $-\cdot / I r V$ & كذشته-مثبت & \\
\hline & & & &.$/ \cdot 4$ & r/V^৭ & . / TFM & حال جبر گرا & \\
\hline & & & & $\cdot / \Delta V F$ & $\cdot / \Delta s p$ & $\cdot / \cdot$ r人 & طرد همسالان & \\
\hline
\end{tabular}

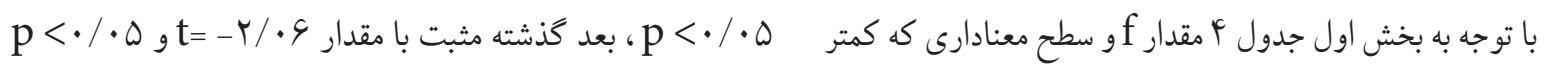

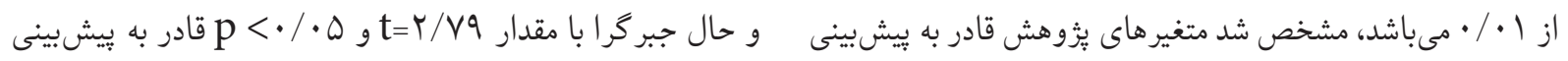

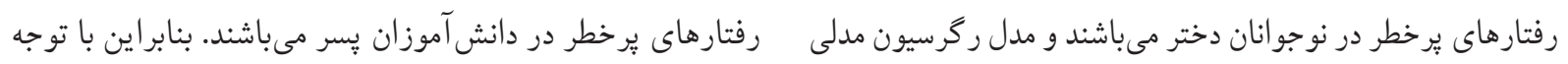

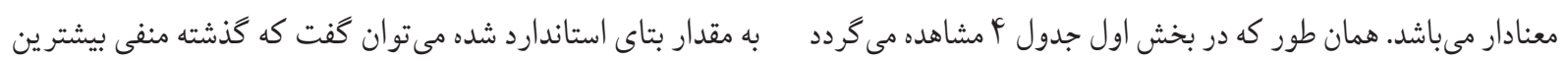

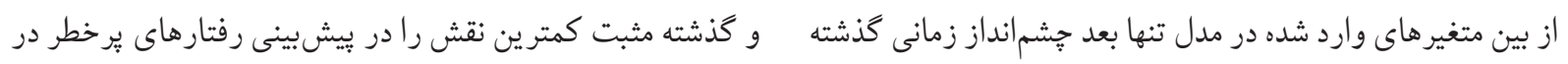

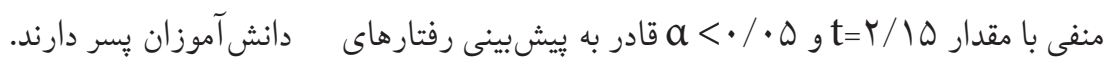

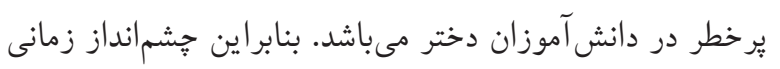

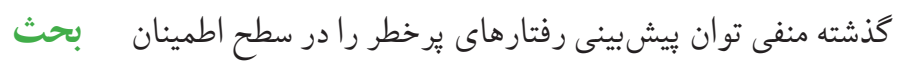

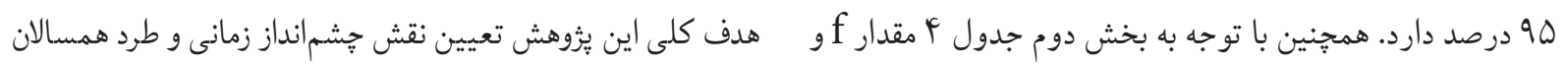

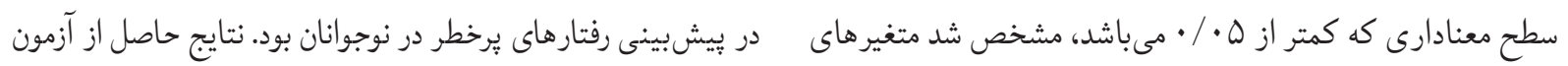

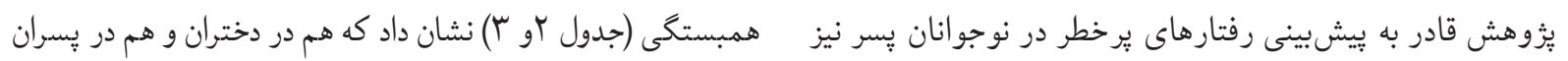

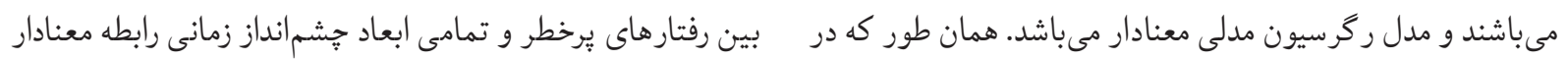

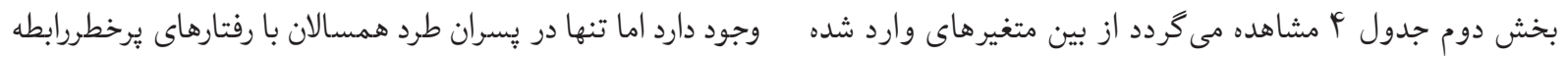

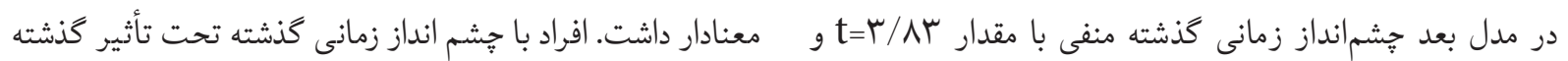


اثر خذيرى از همسالان در اواسط نوجوانى همسوست. در مورد دلايل

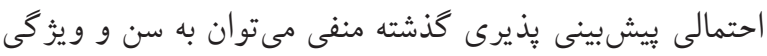

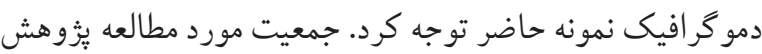

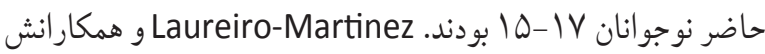
در مطالعهاى مرورى نشان دادند كه بين سن و كذشته منفى رابطه معكوس وجود دارد جرا كه افراد با افزايش سن تا حدودى تمايل كمترى دارند تا افسوس كذشته را بخورند. به همين دليل جشم

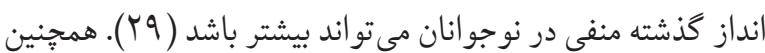
Sircova

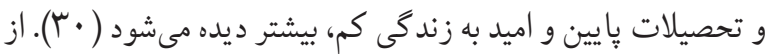

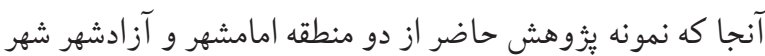

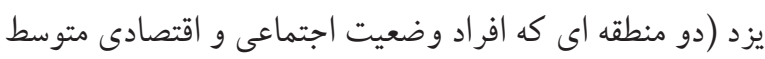

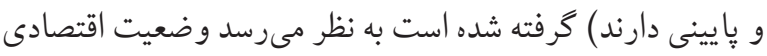

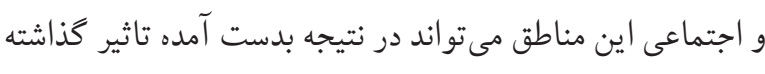

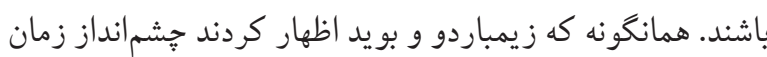
كذشته منفى، نكرشى بطور كلى منفى و آزارنده نسبت به كذشته

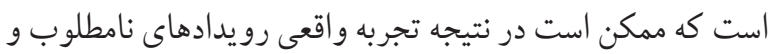

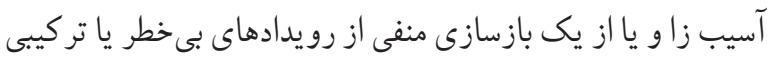

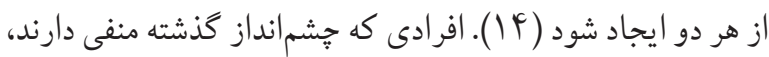
به جاى تمر كز بر آينده، بيشتر به خاطرات تلخ كذشته فكر مى كنند و زمان كمترى راصرف يادكيرى و فعاليتهاى مثبت مى كنند ( آس).

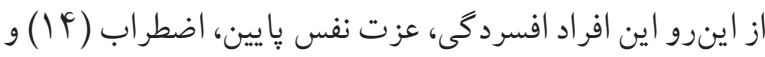

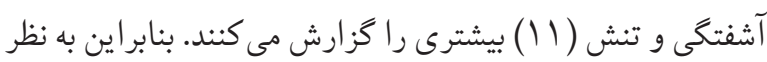
مىرسد تمر كز بر كذشته مىتو اند تفسير نوجوان از موقعيتهايى

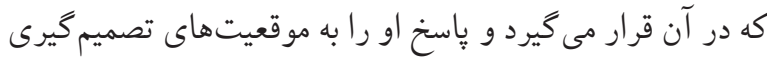

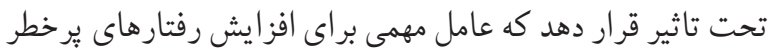

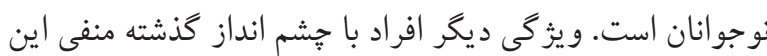

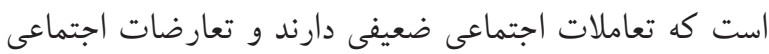
بيشتر و حمايت اجتماعى كمترى را تجربه مى كنند (Tr). در نتيجه

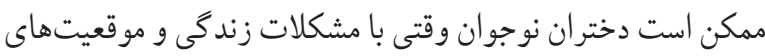
تنشزا روبرو مىشوند، براى رهايى از تنهايى به سمت برقرارى بـ مدرد
خود هستند و اشتغال ذهنى فراوانى با اين دوره زمانى دارند. اگر اين

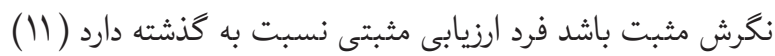
اما اگر اين نكرش منفى باشد تمركز فرد بر تجارب شخصى بد يا

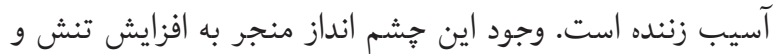

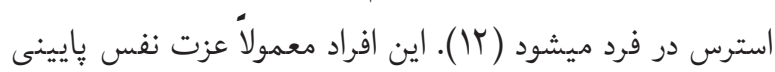

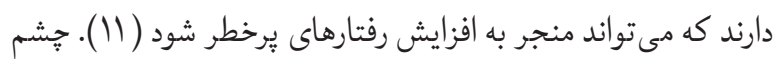

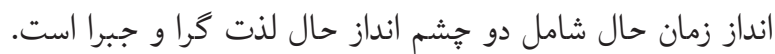
حال جبركرا با ناميدى عمومى و كلى و رفتارهاى آسيب زنينده به ديه

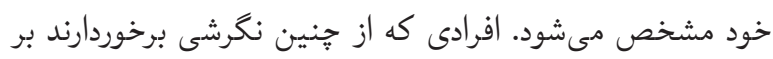
اين باورند كه آينده از يِيش مقدر شده است و اراده و وفت رفتار انسان،

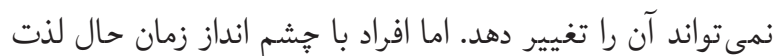
كرا در لحظه زندگى مى كنند، از انجام فعاليتهاى يرانرزى لذت رست مىبردند و در جستجوى هيجانات جديد هستند. اين افراد از تجارب لمركاي

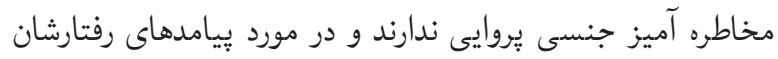

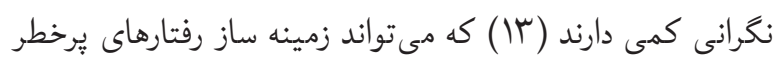

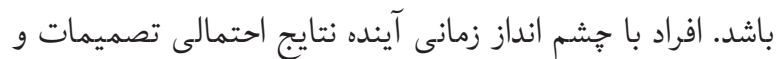

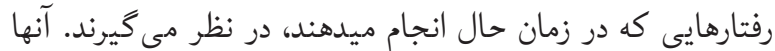
اغلب مى توانند لذتهاى مرتبط با زمان حال را به تاخير بياندازند

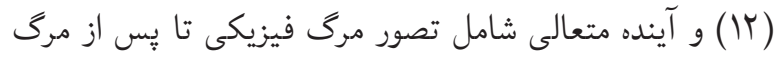

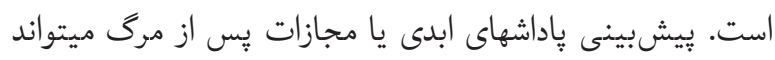

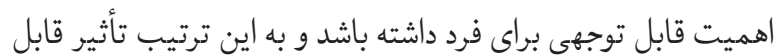

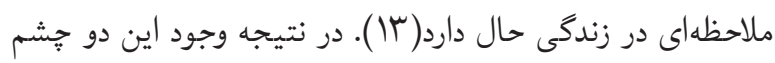
انداز مىتواند منجر به كاهش رفتارهاى يرخطر شود. جهت بررسى دقيقتر نتايج از ركرسيون جند گُانه استفاده شد. نتايج به دست آمده نشان داد از بين ابعاد جشمانداز زمانى و متغير

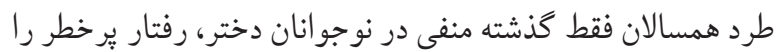
بيش بينى كرد. نتايج حاصل از تحقيق حاضر با نتايج به دست آمده

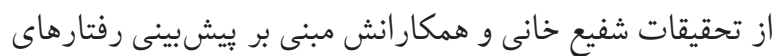
ير خطر توسط بعد جشمانداز زمانى كذشته منفى در دختران (T) و با نتايج McKay و همكارانش در دو جنس (19) و با نتايج Monahan و Steinberg 
يرخاشكرى، ثبات هيجانى ڤايين، عزت نفس پايين و اضطراب

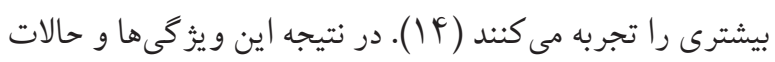

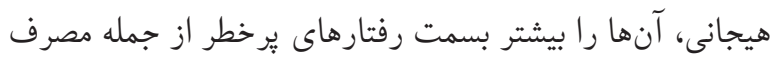
مواد، مصرف سيخار، دوستى با غيرهمجنس و ... سوق مى مهدد.

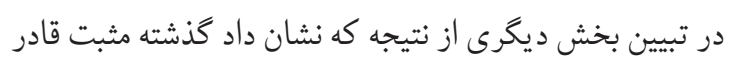

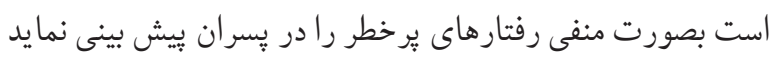

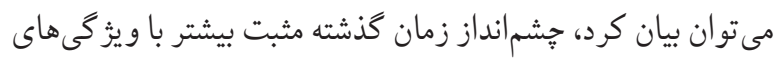

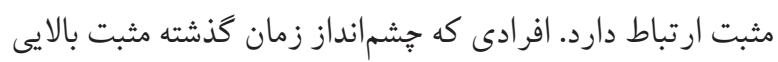

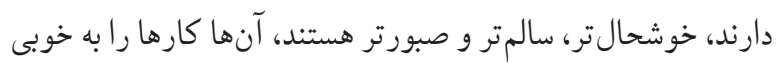
انجام خواهند داد تا نكرش هاى مثبتشان نسبت به كذشته را تقويت كنند (I If). اين افراد نكرشى كرم و احساساتى نسبت به كذشته دارند، تعارضهاى اجتماعى كمتر و حمايتهاى اجتماعى بيشترى را تجربه مى كنند، نكرش دوستانهترى دارند و برعكس افر اد كذشته

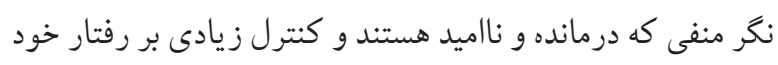

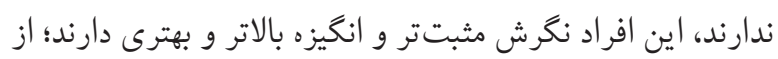

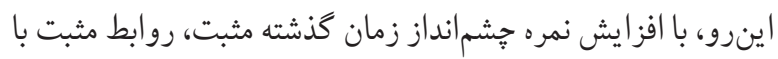

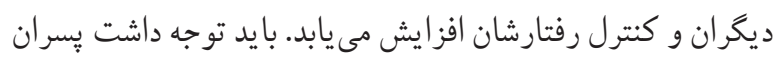

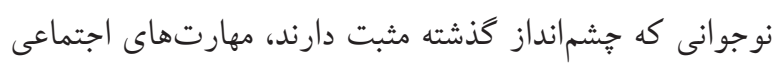

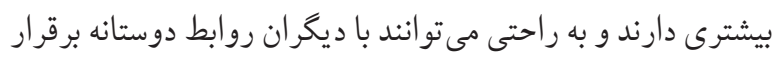

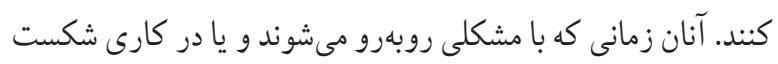

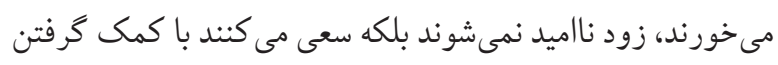

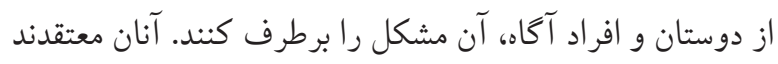

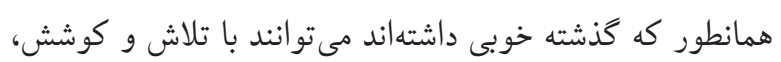

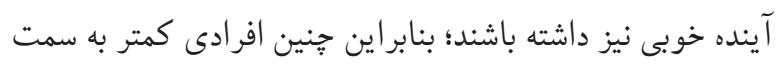
مصرف مواد مخدر گرايش بيدا مى كنند.

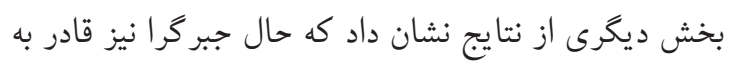

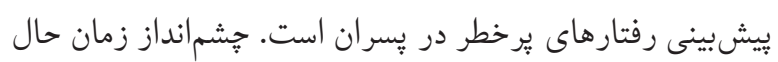

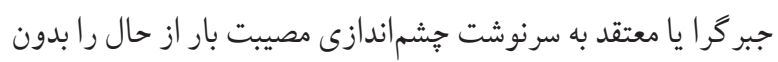

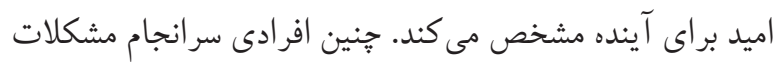

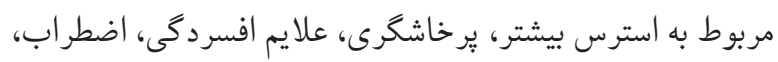

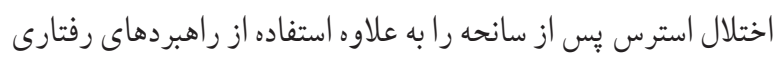

رابطه با جنس مخالف كشيده شوند و يا بواسطه احساس تنشى كه

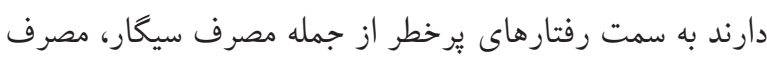
مو اد مخدر و .... كرايش بيدا كنند. يافتها همجنين نشان داد از بين ابعاد جشم انداز زمانى و متغير

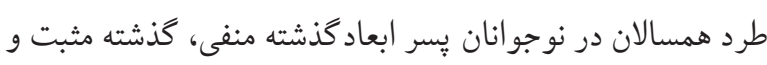

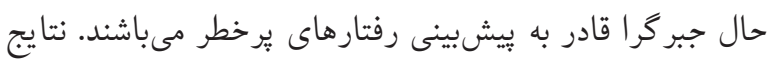

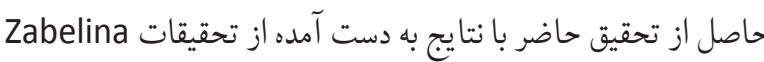

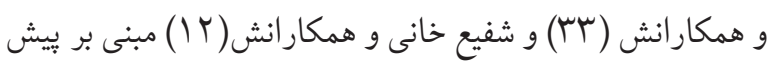

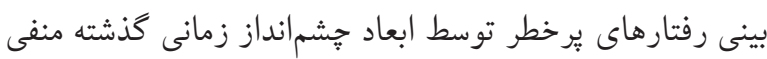

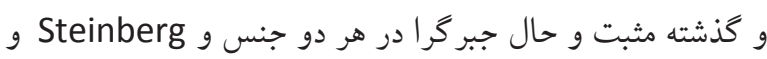
Monahan

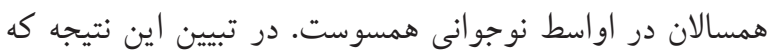

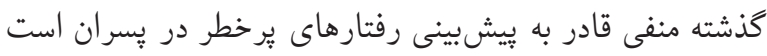

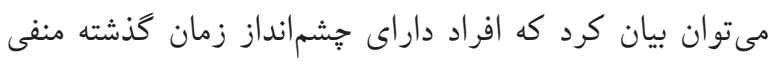

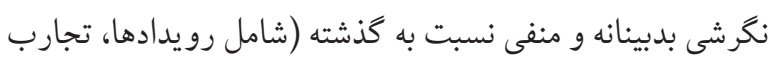

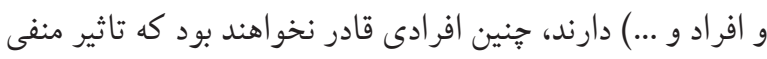
جنين افكارى را بر زندگى خود و بر روابط خويش با ديكران مهار

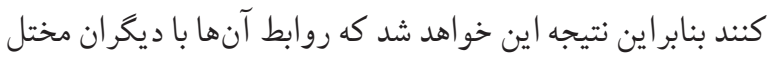
مى گردد و نخو اهند توانست رابطه گرم و توام با اعتماد با ديكران

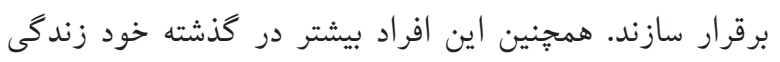

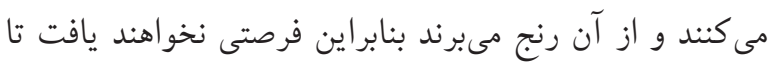
يذيراى تجارب جديد و رسيدگى به رشد شخصى خويش كردند

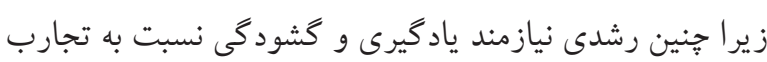

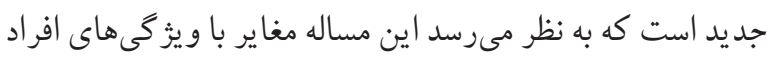

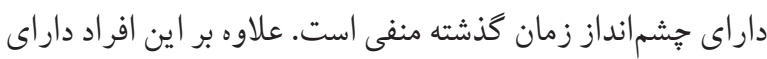

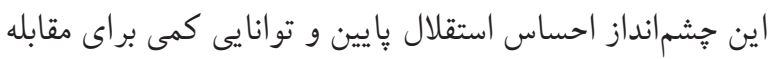

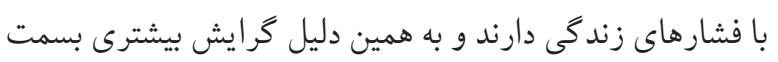

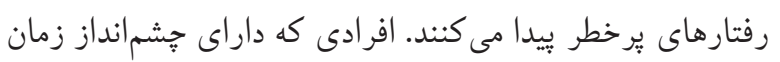
كذشته منفى هستند، روابط بين فردى آنها حداقل و نامطلوب

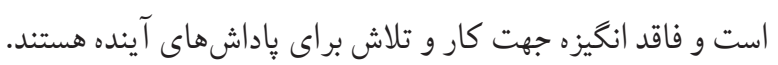

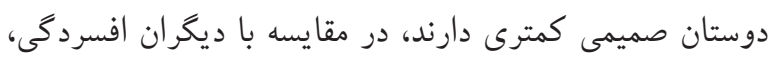


يِيشيرى كننده از رفتارهاى بر خطر مىباشد، كمك شود. همجنين مى توان با آموزش مشاورهاى به آنان در برنامه ريزى و مديريت رفتارهاى يرخطر كمك كرد. از طرفى به مشاوران مدارس بيشنهاد مىشود كه با بر گزارى كارگاههاى آموزشى براى والدين، آنان را با اهميت اين موضوع و ارائه راهكارهاى در جهت ارتقا جشم انداز زمان فرزندانشان آشنا كنند.

نتيجه كيرى: نتايج يزوهش حاضر نشان داد كه در هر دو كروه دختران و پِر ان جشم انداز زمانى قادر است كه رفتارهاى يرخطر را يُش بينى كند اما نقش طرد همسالان معنادار نبود. اين نتيجه ضرورت توجه بيشتر بر متغيرهاى فردى به منظور يِيشيرى از افزايش گرايش نوجوانان به رفتارهاى تيرخطر را نشان ميدهد. ازاينرو به نظر ميرسد بركزارى جلسات آموزشى در خصوص جشم انداز زمانى به نوجوانان بتواند در اين زمينه كمك كننده باشد، جرا كه افراد هنگام قضاوت، تصميم گيرى و عملكردشان، آن را به صورت ناهشيار اعمال ميكنند. تضاد منافع: نويسند كان مقاله اعلام مىدارند، هيج تضاد منافعى در رابطه با نو يسندگى و يا انتشار اين مقاله ندارند. تقدير و تشكر: اين مقاله بر گرفته از يايان نامه كارشناسى ارشد

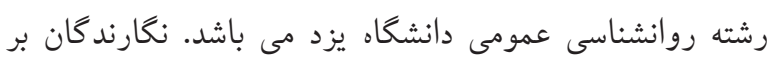
خود لازم مىدانند از كليه مديران و معلمان مدارس و همجنين دانش آموزانى كه در تكميل يرسشنامها با تيم يزوهشى همكارى

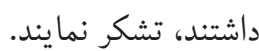

\section{References}

1. Olyani S, Tehrani H, Esmaily H, Rezaii MM, VahedianShahroodi M. Assessment of health literacy with the Newest Vital Sign and its correlation with body mass index in female adolescent students. International Journal of Adolescent Medicine and Health. 2020;32(2):20170103. https://doi.org/10.1515/ijamh-2017-0103

2. Rabie N, Fasihi Harandi T, Qorbani M. A Survey on The Effect of Group-discussion to HIV Prevention in Self-care Vulnerable Women, in Karaj in 2014-2015. Iranian Journal of Health Education and Health Promotion. 2017;5(2):113-20. https://doi.org/10.30699/acadpub.ijhehp.5.2.113
ناساز گارانه و انعطاف نايذير براى حل تعارض تجربه مى كنند. جشمانداز زمان حال جبر گرا با نگرشى ناميد نسبت به زندگى و آينده و عزت نفس يايين رابطه دارد( I F). بايد توجه داشت كه اغلب، يسران نوجوان بلنديروازى هاى خاصى دارند؛ با اين حال اگر آنان جشمانداز حال جبر گر ا داشته باشند به اين نتيجه مىرسند كه آينده از قبل مقدر شده است و تحت تاثير اعمال آنان قر ار نمى گيرد، در اين صورت آنان به تدريج عو امل بيرونى را به عنوان كنترل كننده حوادث مى يذيرند و به دليل نااميدى و غيرمنعطف بودن و منفعل بودن خو يش نمى تواند روابط خوبى با ديخران برقرار كند. بنابراين يسران نوجوانى كه داراى جشمانداز زمانى حال جبر گرا هستند، معتقدند كه نمىتوانند براى داشتن آينده بهتر كارى كنند و آينده آنها از قبل مقدر شده است، بنابراين اين گروه از افراد به احتمال زياد دجار حالات افسردگى و اضطراب مىشوند و از آنجايى كه خود را ناتوان و شكست خورده مى بينند بر ایى رهايى از افكار منفى و مزاحم به سمت رفتارهاى يرخطر مخصوصاً مصرف مواد مخدر،

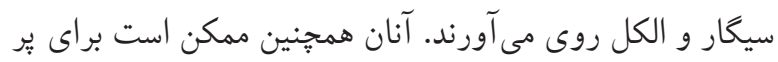
كردن احساس تنهايى خود، به دوستى با جنس مخالف روىى آورند. يزوهش حاضر داراى تعدادى محدوديت بود. اولين محدوديت خود گزارشى بودن يرسشنامهها خصوصاً در زمينه رفتارهاى يرخطر بود كه ممكن است كمتر از حد واقعى كزارش شده باشد. دوم اينكه به دليل عدم همكارى مدارس در تكميل يرسشنامهها خصوصاً رفتارهاى يرخطر از روش نمونه كيرى غيرتصادفى استفاده شد. از سوى ديگر دانش آموزان شركت كننده در اين ثيثوهش از دو منطقه اجتماعى - اقتصادى يزد با وضعيت متوسط و وِايين بودند كه قابليت تعميم نتايج را به تمامى دانش آموزان محدود مى كند. لذا ييشنهاد مى شود در يزٔوهشهاى آتى دانش آموزان با وضعيت اقتصادى اجتماعى بالا نيز مورد بررسى قرار گيرند تازمينه مقايسه آنها فراهم كردد. توجه به اينكه نتايج تحقيق نشان داد جشممانداز زمانى قادر

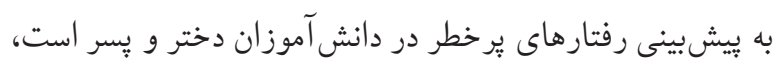
ييشنهاد مى گردد با بر گزارى جلسات آموزشى براى دانش آموزان به آنان جهت آشنايى با انواع خصوصيات ابعاد جشم انداز زمانى كه تركي 
3. zarrinkolah A, Dashti F, Abedi H, Masoudi SM. A Study of Puberty Health Literacy Level of the First 14-16 Year Girls Grade High School Students in the Eghlid City. Journal of Health Literacy. 2016;1(3):164-71. https://doi.org/10.22038/jhl.2016.10964

4. Esmaielzadeh H, Asadi M, Miri N, Keramatkar M. Prevalence of High-Risk Behaviors Among High School Students of Qazvin in 2012. IRJE. 2014; 10 (3): 75-82.

5. Marzban A. Prevalence of High-Risk Behaviors in High School Students of Qom, 2016. JMJ. 2018; 16 (3): 44-51.

6. Igra V, Irwin CE. Theories of adolescent risk-taking behavior. In: Handbook of adolescent health risk behavior. DiClemente RJ, Hansen WB, Ponton LE, editors. Springer: Boston MA; 2013. p. 35-51. https://doi.org/10.1007/978-1-4899-0203-0_3

7. Kritsotakis G, Psarrou M, Vassilaki M, Androulaki Z, Philalithis $A E$. Gender differences in the prevalence and clustering of multiple health risk behaviours in young adults. Journal of advanced nursing. 2016; 72(9):2098-113. h tt p s: / / d o i . org / $10.1111 /$ jan.12981 PMid:27102085

8. Puente D, Zabaleta E, Rodríguez-Blanco T, Cabanas $M$, Monteagudo $M$, Pueyo $M J$, Jané $M$, Mestre N, Mercader M, Bolíbar B. Gender differences in sexual risk behaviour among adolescents in Catalonia, Spain. Gaceta Sanitaria. 2011; 25(1):13-9. https://doi.org/10.1016/j.gaceta.2010.07.012 PMid:21315492

9. Shokri N, Yusefi M, Safaye Rad I, Akbari T, Musavi S, Nazari H. Correlation between risky behaviors in the pre-university adolescent students in Hamadan with Parents' child raising method. JHPM. 2015; 5 (1):73-82.

10. Rashid K. Epidemiology of High-Risk Behaviors among Tehran Adolescent Girls and Boys. Social Welfare. 2015; 15 (57): 31-55.

11. Mello ZR, Walker EB, Finan LU, Stiasny A, Wiggers IC, McBroom KA, Worrell FC. Time perspective, psychological outcomes, and risky behavior among runaway adolescents. Applied Developmental Science. 2018; 22(3): 233-43. https://doi.org/10.1080/10888691.2016.1276455

12. Shafikhani M, Bagherian F, Shokri O. On the Relationship of Time Perspective with Tendency to Substance Abuse in Female Adolescents; Journal of research on addiction, 2016; 10(38): 11-24.

13. Golestaneh SM, Afshin SA, Dehghani Y. The Relationship between the Time Perspective and Achievement Goal, the Academic Procrastination and Academic Achievement of Students in Various Colleges of the University of the Gulf.
Social Cognition Journal. 2016; 5(2): 52-71.

14. Zimbardo P, Boyd J. The time paradox: The new psychology of time that will change your life. New York: Simon and Schuster; 2008.

15. Chavarria J, Allan NP, Moltisanti A, Taylor J. The effects of present hedonistic time perspective and past negative time perspective on substance use consequences. Drug and alcohol dependence. 2015; 152: 39-46. https://doi.org/10.1016/j.drugalcdep.2015.04.027 PMid:26003335

16. McKay MT, Andretta JR, Magee J, Worrell FC. What do temporal profiles tell us about adolescent alcohol use? Results from a large sample in the United Kingdom. Journal of Adolescence. 2014; 37(8): 1319-28. https://doi.org/10.1016/j.adolescence.2014.09.008 PMid:25305444

17. Zentsova NI, Leonov SV. Comparative characteristics of time perspective of professional athletes and drug addicted people. Procedia-Social and Behavioral Sciences. 2013; 78: 340-4. https://doi.org/10.1016/j.sbspro.2013.04.307

18. Mello ZR, Oladipo SE, Paoloni VC, Worrell FC. Time perspective and risky behaviors among Nigerian young adults. Journal of Adult Development. 2019;26(3):161-71. https://doi.org/10.1007/s10804-018-9304-2

19. Steinberg L, Monahan KC. Age differences in resistance to peer influence. Developmental psychology. 2007; 43(6):1531-1543. https://doi.org/10.1037/0012-1649.43.6.1531 PMid:18020830 PMCid:PMC2779518

20. Rahmani M, Ghasemi V, Hashemianfar A. Investigation of the Effect of Social Relations on High-Risk Behaviors of Adolescents of Bojnourd City, Iran. Journal of Applied sociology. 2016; 27(1): 1-26.

21.GioiaF.Peereffectsonriskbehaviour:theimportanceofgroup identity. Experimental Economics. 2017; 20(1): 100-129. https://doi.org/10.1007/s10683-016-9478-z PMid:28286411 PMCid:PMC5326808

22. Daspe M, Arbel R, Ramos M, Shapiro L; Margolin G. Deviant Peers and Adolescent Risky Behaviors: The Protective Effect of Nonverbal Display of Parental Warmth. Journal of research on adolescence. 2018; 21(4): 1-16. htt p s://doi.org/10.1111/jora.12418 PMid:29932277

23. Feenstra H, Ruiter RA, Kok G. Social-cognitive correlates of risky adolescent cycling behavior. BMC public health. 2010; 10(1):408. https://doi.org/10.1186/1471-2458-10-408 
$|F|$

PMid:20624293 PMCid:PMC2915958

24. Kohli A, Remy MM, Binkurhorhwa AK, Mitima CM, Mirind $A B$, Mwinja NB, Banyewesize JH, Ntakwinja GM, Perrin NA, Glass N. Preventing risky behaviours among young adolescents in eastern Democratic Republic of Congo: A qualitativestudy. Global publichealth. 2018;13(9):1241-53. https://doi.org/10.1080/17441692.2017.1317009 PMid:28443367 PMCid:PMC6261778

25. Zadeh Mohammadi A, Ahmadabadi Z, Heidari M. Construction and Assessment of Psychometric Features of Iranian Adolescents Risk-Taking Scale. IJPCP. 2011; 17(3): 218-225.

26. Zimbardo PG, Boyd JN. Putting time in perspective: A valid, reliable individual-differences metric. Journal of Personality and Social Psychology. 1999; 77(6): 1271-1288. https://doi.org/10.1037/0022-3514.77.6.1271

27. Vahid dastjerdi L, Nilforooshan L. Work Hope: The Role of Personal and Social Factors and Family Support. Positive Psychology Journal. 2016; 1(4): 15-28.

28. Tahmasian K, Gholamrezaee M. The Relationship between Self-efficacy and Peer Rejection. Journal of Modern Psychological Researches. 2009; 4(14): 107-123.

29. Laureiro-Martinez D, Trujillo CA, Unda J. Time perspective and age: A review of age associated differences. Frontiers in psychology. 2017; 8:101. https://doi.org/10.3389/fpsyg.2017.00101 PMid:28261119 PMCid:PMC5313535

30. Sircova A, Van De Vijver FJ, Osin E, Milfont TL, Fieulaine N, Kislali-Erginbilgic A, Zimbardo PG. Time perspective profiles of cultures. In: Time perspective theory; review, research and application. Stolarski M, Fieulaine $\mathrm{N}$, van Beek W, editors. Springer: Cham; 2015. p. 169-187. https://doi.org/10.1007/978-3-319-07368-2_11

31.Precin P.Pastnegativetime perspectiveasapredictor ofgrade point average in occupational therapy doctoral students. American Journal ofOccupational Therapy. 2017;5(2):3-31. https://doi.org/10.15453/2168-6408.1264

32. Holman EA, Zimbardo PG. The social language of time: The time perspective-social network connection. Basic and applied social psychology. 2009; 31(2):136-47. https://doi.org/10.1080/01973530902880415

33. Zabelina E, Chestyunina $Y$, Trushina I, Vedeneyeva E. Time Perspective as a Predictor of Procrastination. Procedia-Social and Behavioral Sciences. 2018; 238:87-93. https://doi.org/10.1016/j.sbspro.2018.03.011 